\title{
PPM PENGUSAHA KECIL PEMBUDIDAYAAN BIBIT ANGGUR IMPORT DI PERUM UKA KELURAHAN SEMEMI KECAMATAN BENOWO KOTA SURABAYA
}

\author{
Ari Astutik, SS., M.Pd. ${ }^{1}$, Shanty A.Y.P.S Duwila, SS., M.Pd. ${ }^{2}$, Didik Daryanto, S.P., M.M. ${ }^{3}$ \\ ${ }^{1}$ Universitas Wijaya Putra \\ ${ }^{2}$ Universitas Wijaya Putra \\ ${ }^{3}$ Universitas Wijaya Putra
}

ariastutik@uwp.ac.id, shantyduwila@Gmail.com, ryanto_didik@yahoo.com

\begin{abstract}
Abstrak
Dalam era perkembangan globalisasi banyak masyarakat yang ingin menjadi wirausaha, sehingga banyak orang yang menciptakan usaha-usaha kecil untuk bisa dikerjakan dirumah tapi tetap mendapatkan penghasilan. Pada saat musim pandemi seperti ini bekerja dari rumah atau bisa disebut dengan istilah Work from Home adalah salah satu solusi yang paling efektif. Salah satu usaha rumahan yang sekarang banyak dilirik oleh masyarakat terutama kaum laki-laki adalah budidaya bibit anggur impor. Adapun yang menjadi mitra Program Pemberdayaan Masyarakat (PPM) ini adalah seorang bapak yang bernama Nanang Adianto bekerja sebagai pegawai swasta yang bertempat tinggal di kelurahan Sememi, kecamatan Benowo, yang memiliki hobi dan komunitas peng-Anggur-an dengan spesifikasi pembudidayaan dan pembibitan benih buah anggur impor. Berdasarkan hasil observasi dan wawancara yang dilakukan tim kepada Mitra, bapak Nanang Adianto tersebut mempunyai semangat dan jiwa untuk berwirausaha. Namun, ada 3 hal masalah utama dari budidaya bibit anggur impor adalah 1) produksi dengan pembibitan yang hanya berhasil sekitar $50 \%$,2) pengelolaan keuangan yang tidak rapih terutama terkait laba dan rugi karena keuangan masih tercampur dengan kebutuhan pribadi dan 3) manajemen pemasaran hanya sekitar grup anggur saja belum memaksimalkan teknologi informasi. Metode untuk mengatasi permasalahan atau solusi yang ditawarkan pada mitra ada 3 hal, yaitu 1) pelatihan dan pendampingan mengenai produksi terkait teknik dan tatacara budidaya dapat dilakukan dengan ahlinya baik secara langsung, youtube, workshop via zoom dll, 2) pengelolaan keuangan meggunakan aplikasi "BukuKas" karena lebih sederhana dan mudah digunakan sehingga perkembangan usaha dapat terpantau 3) Pemasaran menggunakan media teknologi informasi meliputi sosial media dan E-commerce. Tujuan dari kegiatan ini adalah untuk memperbaiki perekonomian masyarakat khususnya di masa pandemi serta menghasilkan bibit anggur impor yang berkualitas dan variatif dari bibit, batang, dan buahnya mempunyai nilai ekonomis yang cukup tinggi.
\end{abstract}

Kata Kunci : Wirausaha, Budidaya bibit anggur impor, Aplikasi keuangan, eCommerce.

\section{PENDAHULUAN}

\subsection{Analisis Situasi}

Dalam era perkembangan globalisasi banyak masyarakat yang ingin menjadi wirausaha, sehingga banyak orang yang menciptakan usahausaha kecil untuk bisa dikerjakan dirumah tapi tetap mendapatkan penghasilan. Pada saat musim pandemi seperti ini bekerja dari rumah atau bisa disebut dengan istilah Work from Home adalah 
salah satu solusi yang paling efektif. Salah satu usaha rumahan yang sekarang banyak dilirik oleh masyarakat terutama kaum laki-laki adalah budidaya bibit anggur impor. Tanaman anggur impor mampunyai prospek yang bagus di masa depan, inilah yang menyebabkan anggota komunitas anggur semakin banyak dibanding dengan komunitas tanaman buah ataupun bunga hias lainnya.

Anggur merupakan tanaman asli Eropa dan Asia Tengah yang kini sudah ditanam di berbagai belahan bumi, termasuk di tanah air. Manfaat anggur bagi kesehatan telah didukung banyak peneliti, yaitu mampu menyehatkan jantung, terutama karena kandungan flavonoid, resveratrol, serta polifenolat. Pada simposium internasional mengenai efek kesehatan dari buah-buahan dan sayuran, para ahli menunjukkan konsumsi anggur bisa meningkatkan fungsi jantung, mencegah pembesaran hati dan ginjal, serta mengurangi kerusakan oksidatif pada jantung dan ginjal (Balitjestro, 2021).

Berikut adalah beberapa alasan tentang manfaat pembudidayaan bibit anggur impor:

1) Anggur tidak membutuhkan lahan yang luas karena bisa ditanam halaman rumah dengan lahan yang sangat sempit dan bahkan bisa ditanam di dalam pot dan ditaruh di dak rumah yang bertingkat;

2) Bermanfaat untuk peneduh rumah;

3) Buahnya indah, bentuknya berbeda-beda, dan warna menawan sehingga masyarakat yang menyukai keindahan (tanaman buah hias) baik bapak-bapak maupun ibu-ibu akan lebih mudah tertarik dan mencoba untuk menanamnya;

4) Varietasnya banyak, sehingga selalu membuat penggemar ingin memiliki varietas yang berbeda dan jika dibandingkan dengan tanaman buah atau tanaman hias lainnya yang varietansnya sangat terbatas;

5) Rasanya enak dan berbeda dengan anggur lokal sehingga digemari anak-anak maupun orang dewasa;

6) Harga buah anggur impor di pasaran masih relatif mahal sehingga ada upaya mengkebunkannya baik skala rumahan maupun kebun/industri;

7) Harga pupuk untuk anggur tidak mahal karena bisa menggunakan pupuk organik cair maupun padat. Semuanya bisa dibuat sendiri dengan bahan-bahan yang mudah didapat di sekitar rumah;

8) Anggur juga cocok ketika masa pandemik banyak orang tinggal di rumah dan mengisi waktunya dengan berkebun.

Adapun yang menjadi mitra Program Pemberdayaan Masyarakat (PPM) ini adalah seorang bapak yang bernama Nanang Adianto bekerja sebagai pegawai swasta yang bertempat tinggal di Perum UKA gg 11 no 8, kelurahan Sememi, kecamatan Benowo, kota Surabaya, yang memiliki hobi dan komunitas peng-Anggur-an dengan spesifikasi pembudidayaan dan pembibitan tanaman anggur impor. Berdasarkan hasil observasi dan wawancara yang dilakukan tim kepada Mitra, bapak Nanang Adianto tersebut mempunyai semangat dan jiwa untuk berwirausaha, dan sudah berhasil melakukan pembibitan dan memasarkan produk kepada konsumennya. Namun proses pembibitan mengalami kendala dalam ketidak stabilan hasil bibit sehingga tidak dapat memenuhi semua pesanan bibit konsumen. Beliau dibantu oleh 2 pekerja tidak tetap yang berlatar belakang pendidikan lulusan SMA, sehingga sangat perlu pelatihan agar pembibitan anggur impor lebih banyak dan stabil dan bisa memenuhi semua pesanan konsumen yang tidak terduga atau melimpah setelah pelatihan dan pengembangan dari segi marketing bila sudah berjalan dengan baik dan lancar. Karena untuk mengembangkan dan memperbesar omset penjualannya akan dibantu pada bidang pemasaran.

Konsumen bibit anggur impor mulai berkembang, ini terbukti banyaknya anggota komunitas bibit anggur impor di sosial media khususnya FaceBook yang mencari bibit anggur impor / batang / entres untuk dibeli. Oleh sebab itu mitra berhasil menjual hasil budidayanya berupa bibit anggur impor dengan harga rata-rata $\mathrm{Rp}$. 120.000/ bibit, batang dengan harga Rp. 10.000/ batang, dan entres dengan harga $\mathrm{Rp} \mathrm{10.000/entres}$ (semua tergantung jenis varietas anggur), serta jasa grafting di berbagai tempat bagi yang mempunyai anggur lokal untuk di grafting/ disambung dengan anggur impor. Untuk memperjelas modal dalam 
pembelian bibit anggur indukan, biaya pemupukan, biaya budidaya, dan jasa grafting dibutuhkan manajemen keuangan agar tercatat jelas laba dan rugi.

Namun untuk mengembangkan bibit anggur terutama varietas impor terbilang tidak begitu mudah. Anggur yang tumbuh di luar Indonesia tentunya punya karakteriristik sendiri dan butuh upaya untuk menumbuhkan ditanah diluar lingkungan asalnya. Dan masih ada beberapa kendala yang lain yaitu:

1) Bibit masih mahal sehingga perlu belajar dan praktek pembibitan;

2) Perlu pemahaman media tanam, pemupukan dan penanggulangan hama;

3) Perlu mempelajari teknik penanaman, termasuk cara pembuahan;

oleh karena itu, mitra akan dibekali tambahan kemampuan melalui pelatihan dalam hal pengolahan media tanam dan pembibitan yang efisien dengan melakukan usaha pengembangan bibit anggur impor menggunakan teknik grafting antara anggur lokal yg sudah beradaptasi di Indonesia dengan anggur import yang baru di datangkan langsung dari luar negeri. Grafting sendiri merupakan salah satu metode budidaya tanaman dengan teknik sambung/okulasi. Sementara dalam pengolahan media tanam diperlukan beberapa bahan yang sangat mempengaruhi pertumbuhan tanaman anggur impor dengan sangat baik, hal ini seperti diyanyatakan dalam sebuah penelitian yakni "Hasil penelitian menunjukkan penggunaan media tanam yang terbaik adalah tanah dicampur kompos dan selanjutnya secara berturutturut diikuti oleh media tanah, media campuran tanah dengan arang sekam, dan terakhir adalah media campuran tanah dengan cocopeat. Media tanah (top soil) pada dasarnya sudah mengandung unsur hara yang tersedia bagi tanaman. Sedangkan arang sekam lebih banyak berfungsi secara fisik untuk memperbaiki struktur media tanam" (Gunardi \& Sumiartha, 2019). Pelatihan diberikan agar kendala-kendala tentang pembudidayaan bibit anggur impor bisa diatasi dengan baik dan tepat guna.

\subsection{Profil Mitra (Nanang Adianto)}

1) Mitra adalah karyawan swasta dengan latar belakang pendidikan S1 ekonomi Manajemen yang berawal dari hobi merawat beberapa tanaman buah di rumah, namun jenis tanaman buah yang paling berpotensi untuk menghasilkan profit yang besar adalah tanaman anggur, disamping hasil buah yang menarik dan harga buah yang masih tinggi, semua bagian tanaman anggur bisa di jual belikan (batang tua, batang muda, daun, dan buah). Oleh sebab itu sekarang mitra hanya fokus dalam pengembangan bibit anggur import saja.

2) Mitra dibantu oleh 2 karyawan tidak tetap yang digaji harian. Latar belakang pendidikan mereka adalah lulusan SMA yang masih kurang pengalaman dalam pembibitan anggur import secara efektif dan efisien.

3) Mitra sementara ini mampu menjual 6 bibit sebulan dengan harga penjualan Rp.120.000 per bibit, jadi total pendapatan adalah Rp.720.000,Dengan modal awal Rp.500.000 untuk dapat menghasilkan bibit baru rata-rata 20 bibit tanaman anggur.

\subsection{Permasalahan mitra}

1) Proses pembibitan tingkat keberhasilan nya masih 50\% yang tumbuh dan separuhnya gagal (mati) hal ini dikarenakan alat yang digunakan mitra hanya mengandalkan pisau cutter biasa, namun apabila menggunakan pisau khusus okulasi bisa mempertinggi tingkat keberhasilannya. Perawatan bibit yang baru selesai di grafting juga perlu ditingkatkan, misalnya dengan pupuk khusus bibit kecil yang tepat guna, sehingga bibit tanaman tumbuh sangat subur dan bisa dijual setelah umur 1-3 bulan sejak grafting/ okulasi.

2) Potensi usaha pertanian skala hobi maupun kebun produksi khususnya tanaman anggur sangatlah tinggi (dilihat dari rating group FB tanaman anggur paling banyak) dan usaha pertanian masih menjanjikan karena hampir disetiap rumah mempunyai tanaman dihalamannya. Mitra juga menjual alat serta pendukung pertanian lainnya seperti pupuk, media tanaman, obat perawatan tanaman, pot serta lainnya.

3) Manajemen usaha yang berupa manajemen SDM masih belum dijalankan mitra dengan 
baik, pembagian kerja untuk pembibitan masih belum dijadwalkan. Dalam bisnis tanaman memerlukan waktu untuk pertumbuhan bibit yang akan dijual (1-3 bulan siap jual), maka perlu dijadwalkan pembibitan tiap hari nya bagi anggota kelompok kerja, sehingga jika ada konsumen yang sewaktu-waktu untuk beli bibit, stock bibit selalu tersedia di kebun.

4) Manajemen keuangan tidak dilaksanakan dengan tepat, hasil dari penjualan tidak tercatat seluruhnya, bahkan masih dipakai untuk keperluan pribadi, terkadang biaya untuk perawatan bibit tanaman tidak ada, sehingga bibit tanaman kurang subur dan harga bibit bisa lebih murah.

5) Manajemen pemasaran yang dilakukan mitra masih belum memaksimalkan teknologi yang sangat luas, hanya sebatas area kecil di komunitas tanaman anggur tertentu (group FB), sehingga hanya sebagian komunitas yang mengetahui bibit yang akan di jual oleh mitra.

\section{METODE}

\begin{tabular}{|c|c|c|c|}
\hline No & $\begin{array}{c}\text { Bidang } \\
\text { Masalah }\end{array}$ & Metode Pelalsanaan & Keterangan \\
\hline \multirow[t]{7}{*}{1} & \multirow[t]{7}{*}{$\begin{array}{l}\text { Proses } \\
\text { produksi }\end{array}$} & $\begin{array}{l}\text { Melakoukan pendekatan kepada mitra } \\
\text { dengan pemberdayaan, pelatihan dan saa } \\
\text { proges produksi. }\end{array}$ & $\begin{array}{l}\text { Koordinasi bersama } \\
\text { mitra dengan } \\
\text { melakukan pelatihan } \\
\text { dan pendampingan } \\
\text { gampai proses } \\
\text { produksi. }\end{array}$ \\
\hline & & Pengadaan perlengkapan produksi & $\begin{array}{l}\text { Memberikan Pigau } \\
\text { khusus okulasi } \\
\text { gebanyak } 3 \text { buah. }\end{array}$ \\
\hline & & $\begin{array}{l}\text { Pendampingan penggunaan alat okulasi } \\
\text { gerta telonik okulasi yang benar. }\end{array}$ & $\begin{array}{l}\text { Mitra mengerti } \\
\text { pentingnya alat } \\
\text { okulasi yang bagus } \\
\text { dan steril }\end{array}$ \\
\hline & & $\begin{array}{l}\text { Pengadaan alat pertanian dan } \\
\text { perlengkcapan kebersihan }\end{array}$ & $\begin{array}{l}\text { Sekop sebanyak } 2 \\
\text { buah, sprayer } \\
\text { gebanyak } 3 \text { buah, } \\
\text { jaring paranet } \\
\text { gebanyak } 20 \text { meter } \\
\text { persegi, gapu sebanyak } \\
2 \text { buah, box gampah } \\
\text { gebanyak } 2 \text { buah, box } \\
\text { pupuk sebanyak } 6 \\
\text { buah, sarung tangan } \\
\text { gebanyak } 5 \text { pasang, } \\
\text { gunting gebanyak } 2 \\
\text { buah. }\end{array}$ \\
\hline & & Pengadaan logo dan pembuatan stiker & $\begin{array}{l}\text { Pemberian label, logo } \\
\text { serta identitas tanamam } \\
\text { dan pembuatan stiker }\end{array}$ \\
\hline & & Pendampingan dalam pengemasan & $\begin{array}{l}\text { Koordinasi bersama } \\
\text { mitra dalam } \\
\text { pengemagan saat } \\
\text { pengiriman. }\end{array}$ \\
\hline & & $\begin{array}{l}\text { Melakukan evaluasi gaat pendampingan } \\
\text { proses produksi. }\end{array}$ & $\begin{array}{l}\text { Koordinasi bersama } \\
\text { mitra untuk } \\
\text { mengevaluasi } \\
\text { perkembangan proses } \\
\text { produksi. }\end{array}$ \\
\hline
\end{tabular}

\begin{tabular}{|c|c|c|c|}
\hline \multirow[t]{4}{*}{2} & \multirow[t]{4}{*}{$\begin{array}{l}\text { Manajemen } \\
\text { walha }\end{array}$} & $\begin{array}{l}\text { Melakukan pendesatan kepoda anitra } \\
\text { dengan penkerdayaan, pelatiha dan } \\
\text { pendampingan saat proses kegiatan } \\
\text { kerja }\end{array}$ & $\begin{array}{l}\text { Koocdinasi bersama } \\
\text { mitna dalam } \\
\text { melakukan } \\
\text { pendampingan saat } \\
\text { poses keriatan keria. }\end{array}$ \\
\hline & & $\begin{array}{l}\text { Melakukan pendampingon serkait } \\
\text { manajemen SDM dalam pembagian } \\
\text { kerja }\end{array}$ & $\begin{array}{l}\text { Menbout pembagian } \\
\text { tugas herja }\end{array}$ \\
\hline & & $\begin{array}{l}\text { Melakuka pendampingan dalam } \\
\text { pembuatan laporan heuangan dengan } \\
\text { aplikasi buku Kas }\end{array}$ & $\begin{array}{l}\text { Kooddinasi bersama } \\
\text { mitra dalam membuat } \\
\text { lapora keuangan } \\
\text { dengan menggunakan } \\
\text { aplikasi belou kas. }\end{array}$ \\
\hline & & $\begin{array}{l}\text { Melakukan evaluast hasil } \\
\text { pendampingas saat proses } \\
\text { pendampingas }\end{array}$ & $\begin{array}{l}\text { Koocdinasi bersama } \\
\text { mitra wouk } \\
\text { mengevahasi hasil } \\
\text { pendampingan. }\end{array}$ \\
\hline \multirow[t]{5}{*}{3} & \multirow[t]{5}{*}{ Pemasainall } & $\begin{array}{l}\text { Melakukan penderatan kepada mitra } \\
\text { dengan penberdayaan, pelatihas dan } \\
\text { pendampingas saat proses pemasaran }\end{array}$ & $\begin{array}{l}\text { Kooddinasi bersama } \\
\text { mitra dalam } \\
\text { melakukan pelatiluan } \\
\text { dun pesdumpingan } \\
\text { sat proses pemasaran. }\end{array}$ \\
\hline & & $\begin{array}{l}\text { Melakukan pendampingan saat } \\
\text { pembuatan akun media sosial } \\
\text { (Facebook dan tokopodia) }\end{array}$ & $\begin{array}{l}\text { Kooddinasi bersama } \\
\text { mitrz dalam } \\
\text { melakukan } \\
\text { pendampingan saat } \\
\text { pembuata akun media } \\
\text { sosial. }\end{array}$ \\
\hline & & $\begin{array}{l}\text { Melakukan pendampingan saat menjalin } \\
\text { hoocksi dengan pihak yang } \\
\text { berhubungan dengan pemakara mitra }\end{array}$ & $\begin{array}{l}\text { Kooddinasi bersama } \\
\text { mitra dalam } \\
\text { pendampinga saat } \\
\text { menjalia hoocksi } \\
\text { dengan calon } \\
\text { hoeournea. }\end{array}$ \\
\hline & & $\begin{array}{l}\text { Melakukan pendampingan penasaran } \\
\text { melalui media teknologi yang ielah } \\
\text { dibuat }\end{array}$ & $\begin{array}{l}\text { Koocdinasi bersama } \\
\text { mitra dalam } \\
\text { melakukan pensasaran } \\
\text { melalui media } \\
\text { teknologi yang telah } \\
\text { dibuat. }\end{array}$ \\
\hline & & $\begin{array}{l}\text { Melakukan evaluasi hasil } \\
\text { pendampingan saat proses manajemen } \\
\text { cosalu. }\end{array}$ & $\begin{array}{l}\text { Koocdinasi bersama } \\
\text { mitra dalam } \\
\text { mengevalasi hasil } \\
\text { pendampingan saat } \\
\text { proses manajemen } \\
\text { waha. }\end{array}$ \\
\hline
\end{tabular}


pencahayaan dan kebersihan),
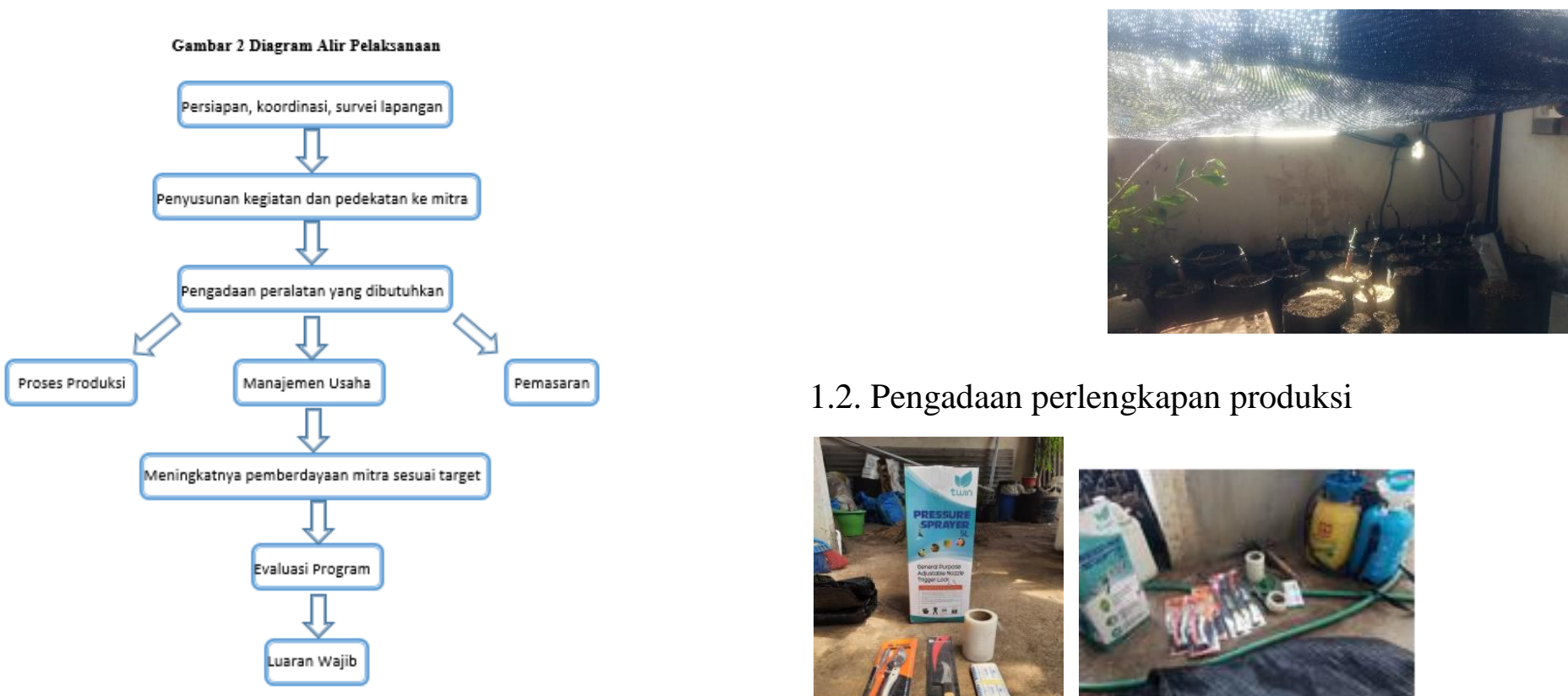

1.2. Pengadaan perlengkapan produksi
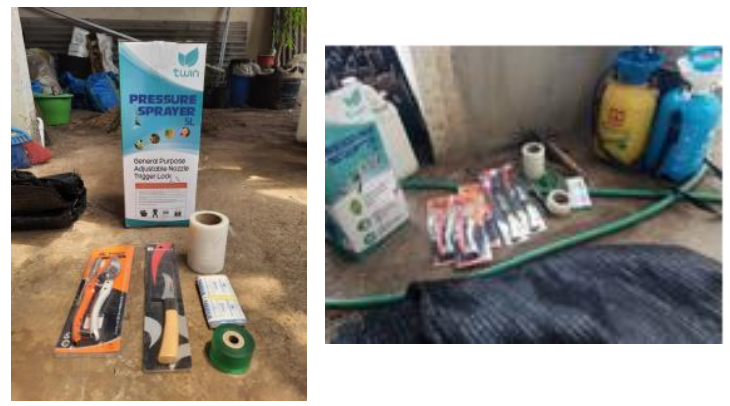

Metode yang digunakan adalah pendampingan personal terhadap mitra adalah sebagai berikut

1) Proses produksi;

1.1. Melakukan pendekatan kepada mitra dengan pemberdayaan, pelatihan dan pendampingan.
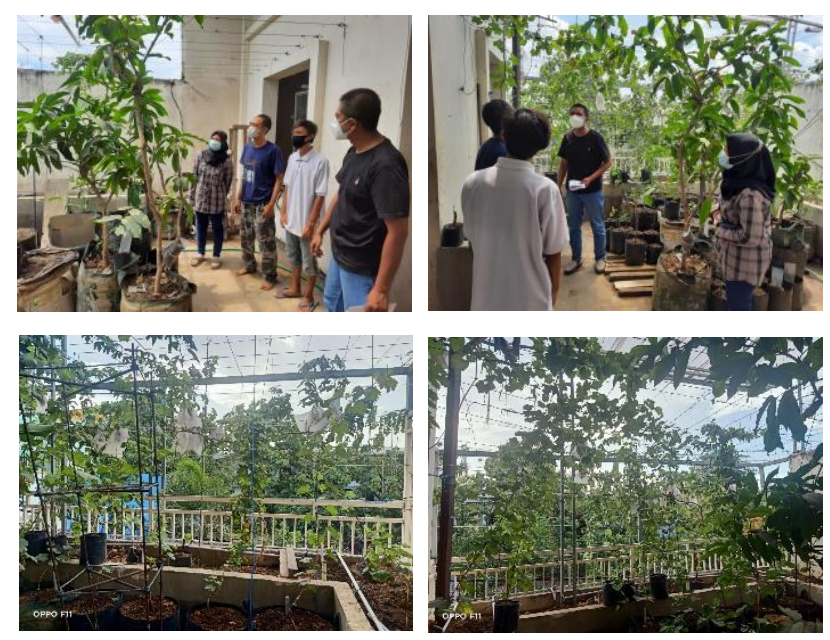

Gambar diatas memerlihatkan bahwa mitra mendapatkan pelatihan dan pendampingan tata letak lahan, menata ulang kebun (letak,
Memberikan Pisau khusus okulasi sebanyak 3 buah.

1.3. Pendampingan penggunaan alat okulasi serta teknik okulasi yang benar.
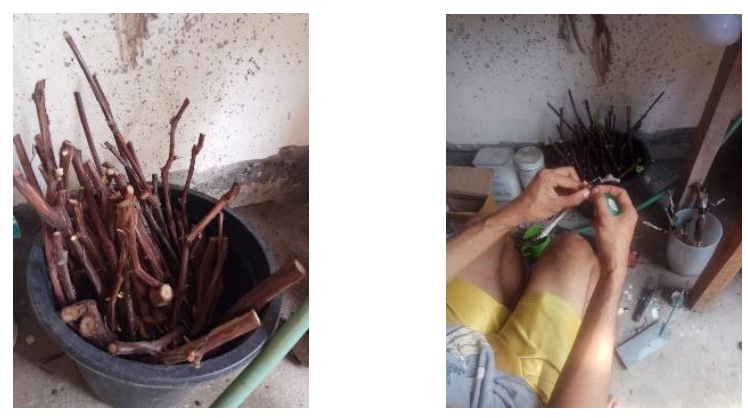

Mitra sudah mengerti pentingnya alat okulasi yang bagus dan steril serta mempraktekannya dalam proses produksi mandiri.

1.4. Pengadaan alat pertanian dan perlengkapan
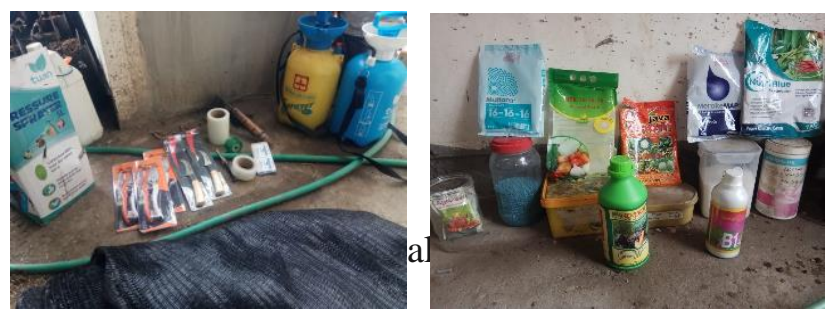
Tersedianya alat pertanian dan perlengkapan sebagai berikut: Sekop sebanyak 2 buah, sprayer sebanyak 3 buah, jaring paranet sebanyak 20 meter persegi, sapu sebanyak 2 buah, box sampah sebanyak 2 buah, box pupuk sebanyak 6 buah, sarung tangan sebanyak 5 pasang, gunting sebanyak 2 buah.

\subsection{Pengadaan logo dan pembuatan stiker}

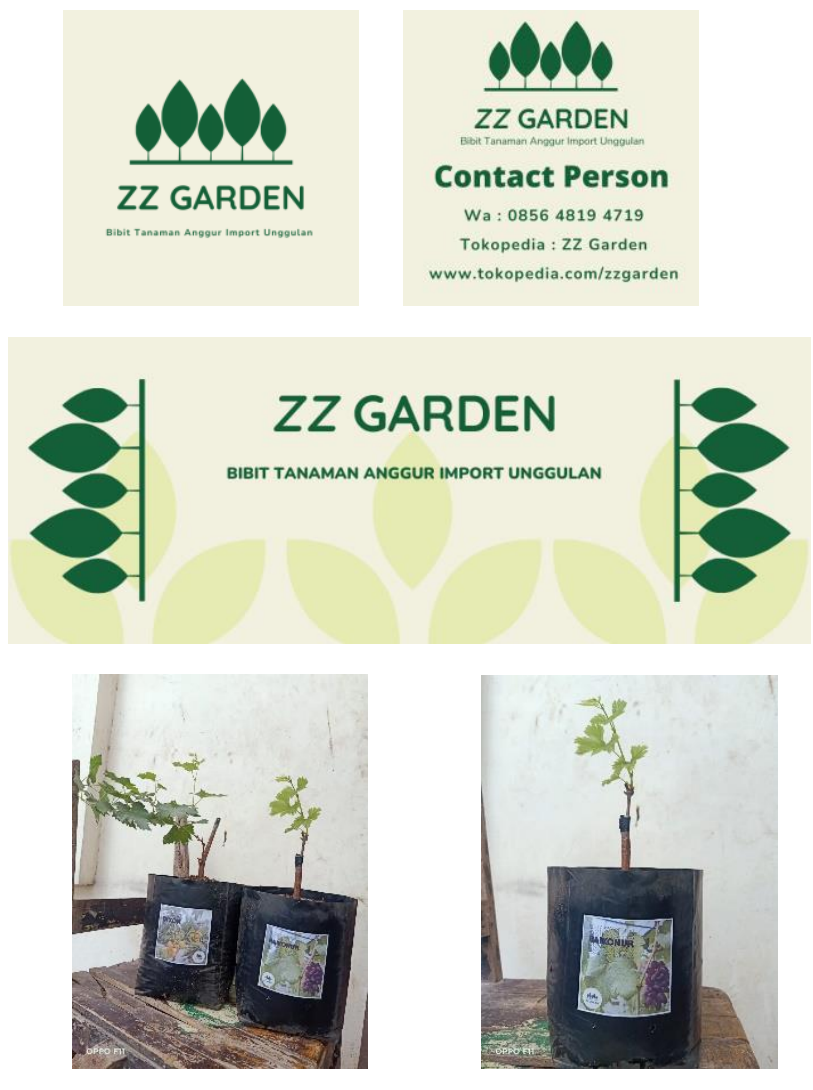

Pemberian label, logo serta identitas tanaman dan pembuatan stiker

1.6. Melakukan evaluasi saat pendampingan proses produksi.

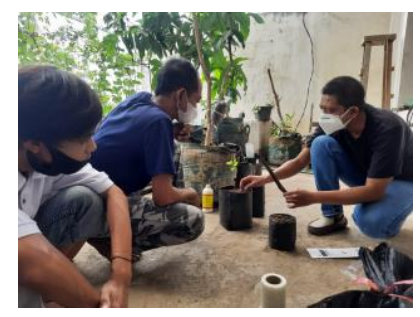

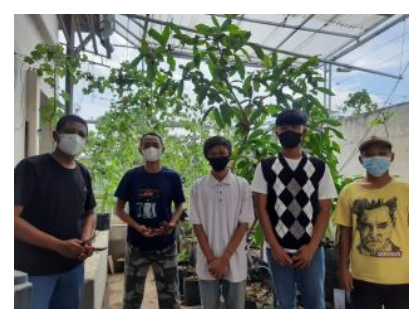

Koordinasi bersama

mitra untuk mengevaluasi perkembangan proses produksi.

\subsection{Pendampingan dalam pengemasan}
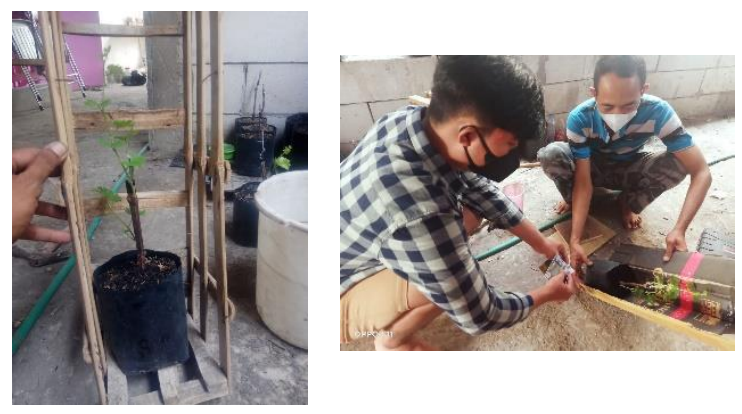

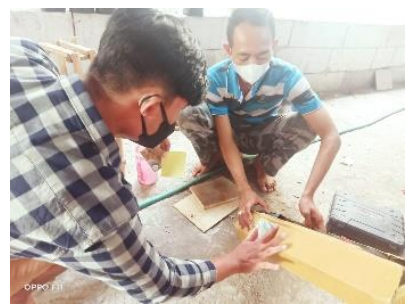

Koordinasi bersama

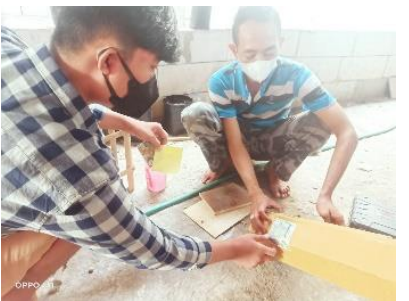

mitra dalam pengemasan saat pengiriman.

Dalam pengemasan, mitra menggunakan packing kayu kemudian dibungkus dengan packing kardus dan diakhiri dengan pemberian label bibit anggur yang dipesan agar pesanan bisa sampai ke tempat tujuan dengan aman.

2. Manajemen usaha

2.1. Melakukan pendekatan kepada mitra dengan pemberdayaan, pelatihan dan pendampingan saat proses kegiatan kerja

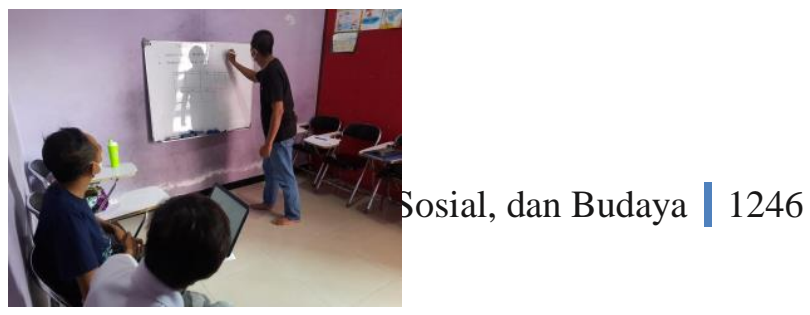


Koordinasi bersama mitra dalam melakukan pendampingan saat proses kegiatan kerja.

2.2. Melakukan pendampingan terkait manajemen SDM dalam pembagian kerja

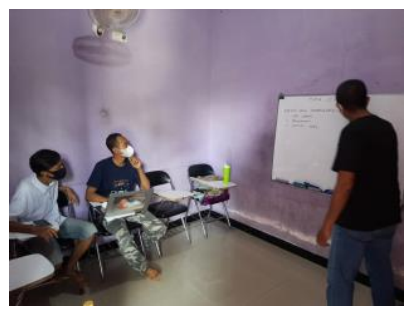

Membuat pembagian tugas kerja

2.3. Melakukan pendampingan dalam pembuatan laporan keuangan dengan aplikasi BukuKas

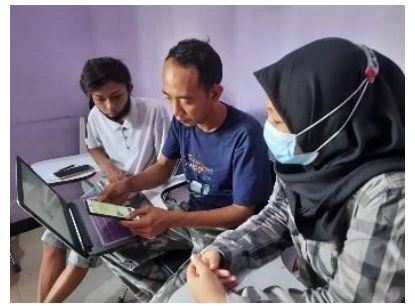

Koordinasi bersama mitra dalam membuat laporan keuangan dengan menggunakan aplikasi BukuKas.

2.4. Melakukan evaluasi hasil pendampingan saat proses pendampingan

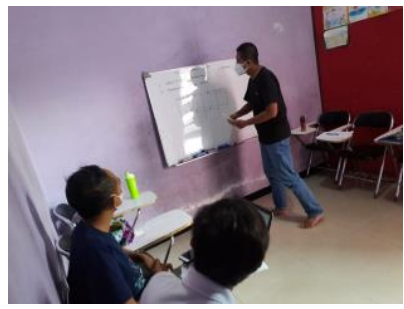

Mitra sedang dievaluasi tentang kemajuan proses pembibitan, manajemen, dan keuangan.

3. Pemasaran
3.1. Melakukan pendekatan kepada mitra dengan pemberdayaan, pelatihan dan pendampingan saat proses pemasaran

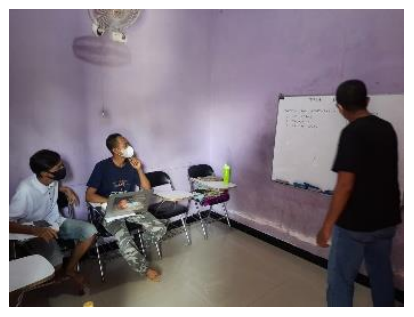

3.2. Melakukan pendampingan saat pembuatan akun media sosial (Facebook dan Tokopedia)

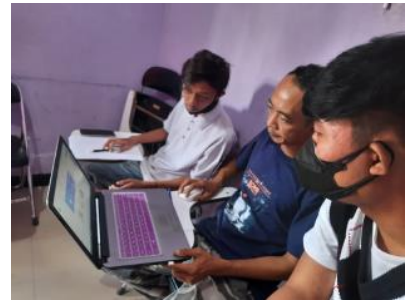

Koordinasi bersama mitra dalam melakukan pendampingan saat pembuatan akun media sosial.

3.3. Melakukan pendampingan saat menjalin koneksi dengan pihak yang berhubungan dengan pemasaran mitra

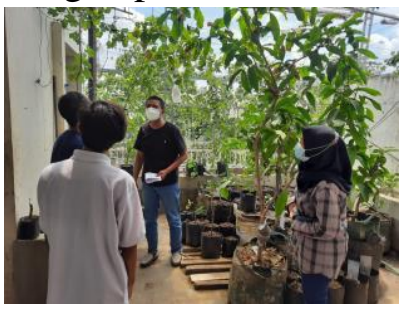

Koordinasi bersama mitra dalam pendampingan saat menjalin koneksi dengan calon konsumen.

3.4. Melakukan pendampingan pemasaran melalui media teknologi yang telah dibuat 


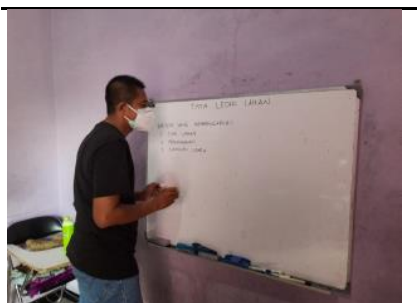

Koordinasi bersama mitra dalam melakukan pemasaran melalui media teknologi yang telah dibuat.

3.5. Melakukan evaluasi hasil pendampingan saat proses manajemen usaha.

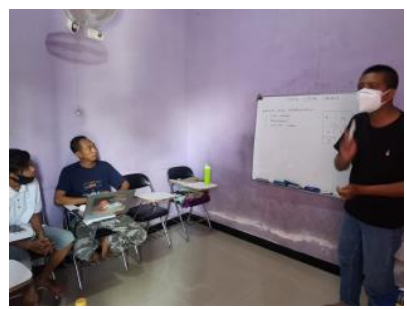

Koordinasi bersama mitra dalam mengevaluasi hasil pendampingan saat proses manajemen usaha.

\section{HASIL DAN PEMBAHASAN}

Tujuan dari dilakukannya kegiatan ini adalh untuk membudidayakan bibit buah anggur dan selain itu juga bertujuan untuk meningkatkan sumber daya manusia agar lebih jadi baik lagi.

Berikut hasil dari kegiatan ini:

1) Stok dan Hasil jadi Bibit Anggur
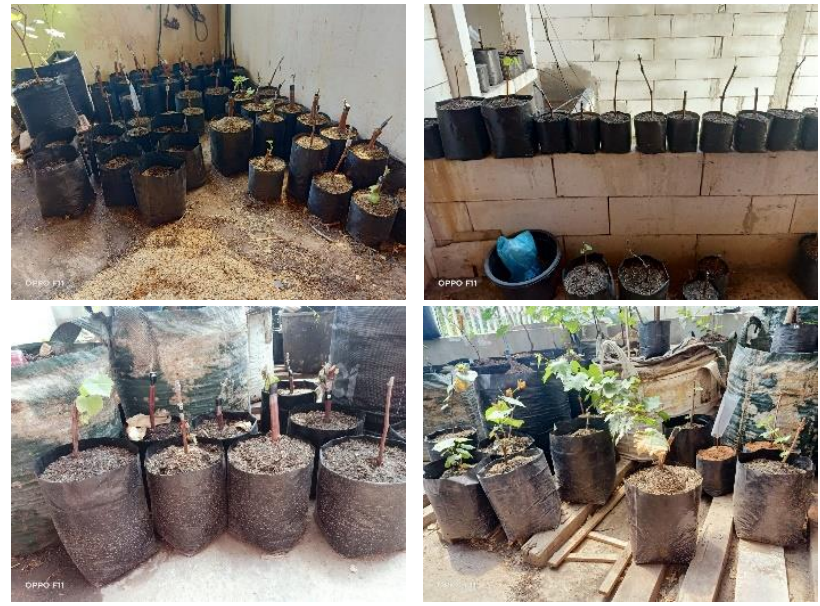
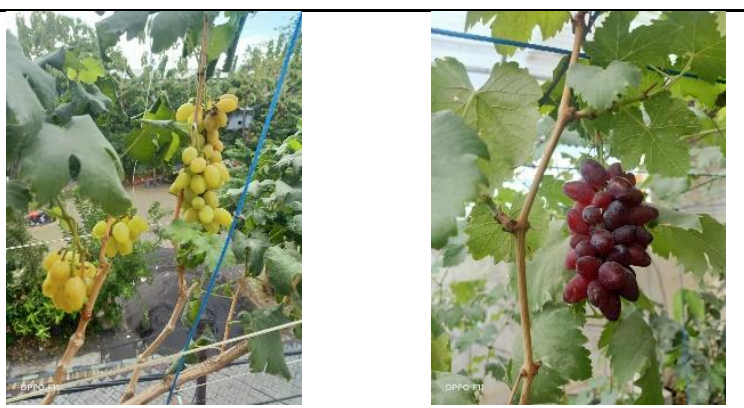

2) Sistem keuangan yang menggunakan aplikasi Buku Kas

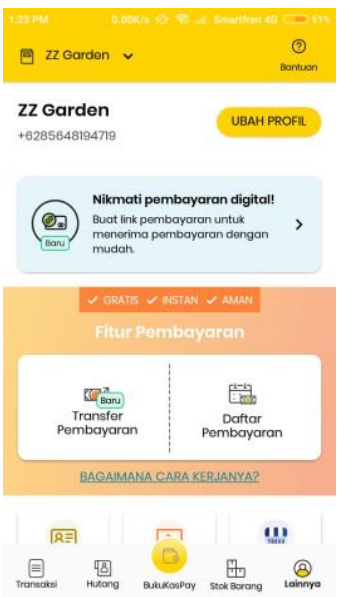

3) Hasil jadi Label, Logo dan Toko Online yang kami buat dan pasarkan secara online dengan

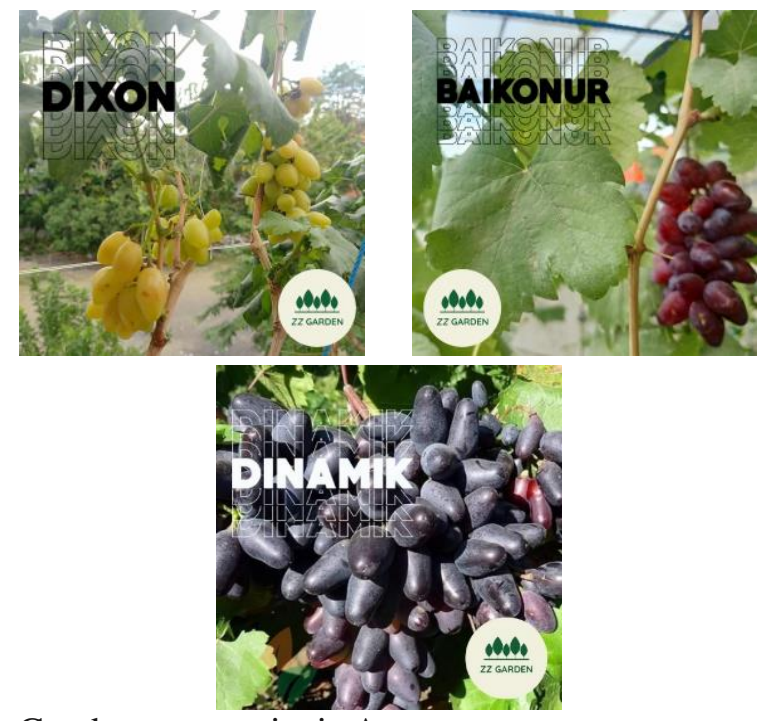

Gambar macam jenis Anggur

Ekonomi, Sosial, dan Budaya 1248 


\section{KESIMPULAN}

Berdasarkan makalah diatas dapat disimpulkan bahwa makalah PPM pengusaha kecil pembudidayaan bibit anggur import yaitu kegiatan berkaitan dengan usaha kecil yang membudidayaan bibit anggur import. Dari makalah ini juga kita bisa belajar bagaimana cara menanam bibit anggur import, pelatihan dan pendampingan mengenai produksi terkait teknik dan tatacara budidaya yang dapat diakses melalui youtube, workshop via zoom dll, pengelolaan keuangan meggunakan aplikasi "BukuKas" karena lebih sederhana dan mudah digunakan sehingga perkembangan usaha dapat terpantau, dan Pemasaran menggunakan media teknologi informasi meliputi sosial media dan Ecommerce. Tujuan dari kegiatan ini adalah untuk memperbaiki perekonomian masyarakat khususnya di masa pandemi serta menghasilkan bibit anggur impor yang berkualitas dan variatif dari bibit, batang, dan buahnya mempunyai nilai ekonomis yang cukup tinggi.

\section{UCAPAN TERIMAKASIH}

Alhamdulillah berkat rahmat dan karunia dari Allah SWT hingga saat ini Universitas Wijaya Putra sudah menyelesaikan PPM pengusaha kecil pembudidayaan bibit anggur import di Perum Uka, kelurahan Sememi, kecamatan Benowo, kota Surabaya.

Untuk itu, saya selaku ketua pelaksanaan mengucapkan terima kasih kepada Bapak Nanang Adianto yang sudah berperan sebagai mitra untuk pembuatan makalah ini. Saya selaku ketua pelaksana berharap semoga usaha kecil Bapak Nanang Adianto bisa berjalan dengan lancar dan sukses. Saya juga berharap semoga PPM ini bisa menjadi pemicu orang-orang untuk menanam bibit anggur import.

\section{REFERENSI}

Balitjestro, 2021, Prospek Pengembangan Varietasvarietas Unggul Anggur di Daerah Sentra Produksi. Online, http://balitjestro.litbang.pertanian.go.id/pros pek-pengembangan-varietas-varietasunggul-anggur-di-daerah-sentra-produksi/, diakses 10 April 2021

Gunadi, Alit, I Gusti \& Sumiartha, I Ketut, 2019, Pertumbuhan Bibit Anggur Prabu Bestari Asal Okulasi pada Berbagai Campuran dan Kandungan Air Media Tanam. Jurnal Agrotop, vol: 9(1):42-55. 